Kalpa Publications in Civil Engineering
Volume 1, 2017, Pages 403-409
ICRISET2017. International Conference on Re-
search and Innovations in Science, Engineering
\&Technology. Selected papers in Civil Engineering $\quad \mathrm{Ka} \mathrm{Loo}$

\title{
A Design Comparison of Castellated Beam for Different Parameters
}

\author{
${ }^{1}$ Vimleshkumar V. Agrawal and ${ }^{2}$ Darshna R. Bhatt \\ ${ }^{1}$ Assistant Professor, Structural Engineering Department, BVM-VVNagar,Anand \\ ${ }^{2}$ Associate Professor, Structural Engineering Department, BVM-VVNagar,Anand
}

\begin{abstract}
Castellated Beams made from steel I Sections are being extensively used in structural applications because it has high moment of inertia and high strength to weight ratio. This paper is concerned with the comparison of castellated beam with solid beam, also carried out for same loading and geometric condition. Parametric study is done by changing various parameters of castellated beam like shape of opening, welded length, ratio of depth of opening to total depth and angle of cut. By comparing castellated beam with solid beam it is concluded that solid beam required higher section.
\end{abstract}

\section{Introduction}

Since Second World War structural designer have explored many ways of decreasing the cost of steel structures. But have often been prevented from utilizing the high strength property of structural steel by building code requirements on maximum allowable deflection to get best advantage. As a result several new methods have been devised to increase stiffness of steel member, without any increase in weight of steel required. Castellated beam is one of the best solutions.

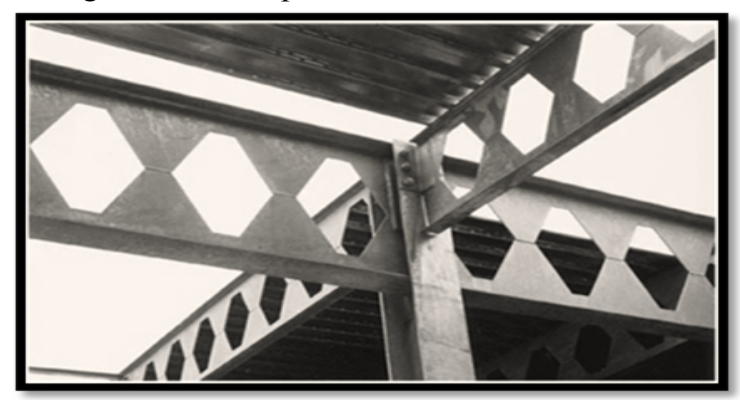

Figure 1: Castellated beam 


\section{Methods of Analysis}

Few different methods presently used are described in brief as follows.

\section{A. ELEMENTARY BENDING THEORY}

In this method, reduced web section is considered in calculating stress and deflection in beams. Results calculated by this method deviate appreciably from the actual value because of neglecting local bending in the T-section.

B. VIERENDEEL ANALYSIS In this method, apart from considering longitudinal stresses due to bending, stresses' arising in the T-section due to local bending from shear force is also considered.

\section{FRAME ANALYSIS}

In this method, beam is treated as rigid frame with members of variable moment of inertia between joints. Flexibility approach by this method was carried out by Sherbourne ${ }^{9}$. A stiffness approach was carried out by Srimani ${ }^{13}$ and Das where the deflection results were quite encouraging.

D. FINITE DIFFERENCE METHOD

This method is used for finding elasticity solution. For bending and shear loading where there was a good agreement between the theoretical and experimental results.

\section{E. FINITE ELEMENT TECHNIQUE}

In this method, treating castellated beam as a plane stress problem was analyzed by Srimani and Das, where a combination of rectangular and triangular elements covering the web and axially loaded bar elements replacing the flanges were considered.

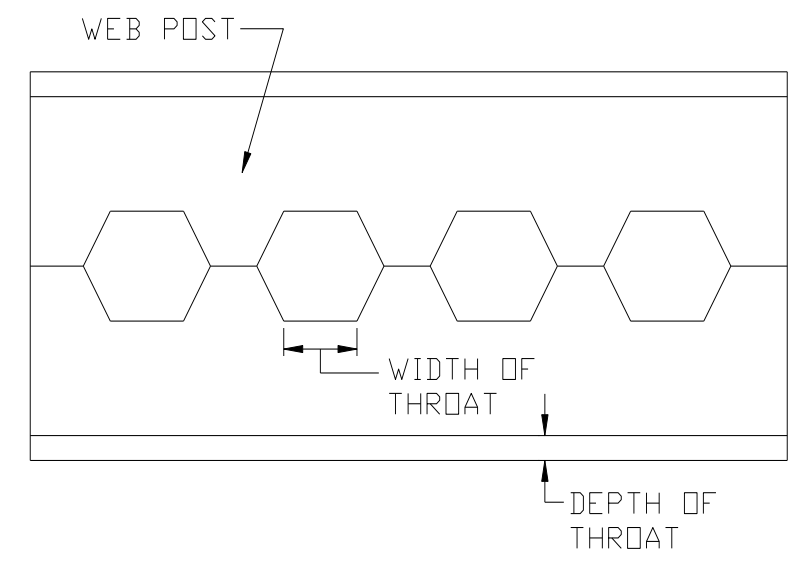

Figure 2: Section castellated beam

\section{Methodology}

A typical castellated beam along with its two sections in solid and open panel is shown in figure 3.The figure also describes the different parameters of the section. Castellated beams made from 48 Indian Standard rolled beams and 27 Indian Standard Channel Section have been considered for properties calculations. These sections are designated, for example, like CLB 600 and CLC 400 corresponding to rolled beam ISLB 600 and Channel ISLC 400 respectively. 

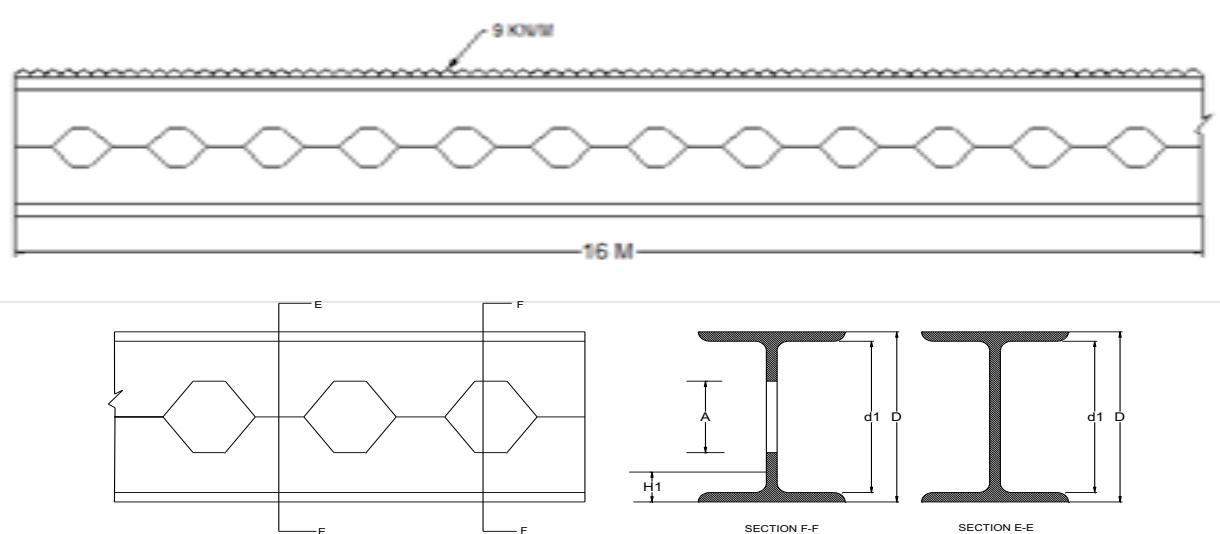

Figure 3: Sectional properties

$\mathrm{W}=$ Unit weight of beam section.

$\mathrm{H} 1=$ c.g. distance of T-section from extreme fibre of flange.

$\mathrm{Ig}=\mathrm{Gross}$ moment of inertia of a castellated beam.

$\mathrm{IN}=$ Net moment of inertia of a castellated beam.

$\mathrm{IT}=$ Moment of inertia of T-section.

$\mathrm{ZXX}=$ Net section modulus of castellated beam.

$\mathrm{A}=$ Depth of hole of castellated beam.

\section{Comparison of Castellated Beam}

Design a laterally restrained castellated beam for a span of $16 \mathrm{~m}$ to support a uniformly distributed load $9 \mathrm{KN} / \mathrm{M}$ Assume angle of cut 60 degree. In this comparison, castellated beam and Solid steel beam having same span and load is designed as per IS-800- 2007 and Minimum Requirement of Section is found out for different loading conditions.

\begin{tabular}{|c|c|c|c|}
\hline \multirow{2}{*}{ No } & \multirow{2}{*}{ Loading condition } & \multicolumn{2}{|c|}{ Minimum Requirement of Section } \\
\cline { 3 - 4 } & UDL & Castellated Beam & Solid Beam \\
\hline 1 & CMB-450 & ISWB-550 \\
\hline 2 & UDL with one point load & CMB-450 & ISLB-600 \\
\hline 3 & UDL with two point load & CMB-450 & ISMB-600 \\
\hline 4 & UDL with three point load & CWB-450 & ISMB-600 \\
\hline
\end{tabular}

Table 1: Comparison between castellated beam \& solid beam for minimum requirement of section

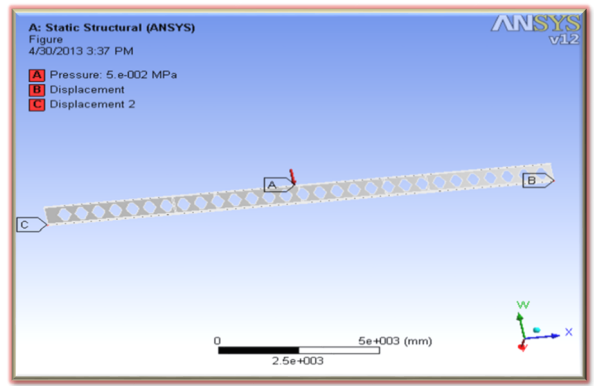

Figure 4: Model (Hexagonal opening)

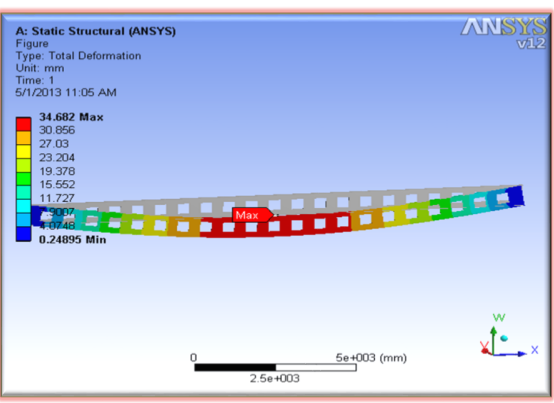

Figure 5: Square opening 
A. Solid beam to castellated beam

In this comparison, deflection is found out by increasing the load on castellated beam and solid beam having same span and same section. The Ansys model of Deflection is shown in figure 4, 5, 6 and 7.

\begin{tabular}{|c|l|l|c|c|}
\hline \multirow{2}{*}{ No } & \multirow{2}{*}{ Section } & \multirow{2}{*}{ Load } & \multicolumn{2}{|c|}{ Deflection } \\
\cline { 4 - 5 } & & & Castellated Beam & Solid Beam \\
\hline 1 & ISMB-500 & $6 \mathrm{KN} / \mathrm{M}$ & $25.72 \mathrm{~mm}$ & $56.61 \mathrm{~mm}$ \\
\hline 2 & ISMB-500 & $9 \mathrm{KN} / \mathrm{M}$ & $38.58 \mathrm{~mm}$ & $84.92 \mathrm{~mm}$ \\
\hline 3 & ISMB-500 & $12 \mathrm{KN} / \mathrm{M}$ & $51.44 \mathrm{~mm}$ & $113.28 \mathrm{~mm}$ \\
\hline 4 & ISMB-500 & $15 \mathrm{KN} / \mathrm{M}$ & $64.30 \mathrm{~mm}$ & $141.53 \mathrm{~mm}$ \\
\hline
\end{tabular}

Table 2: comparison between castellated beam and solid beam for deflection

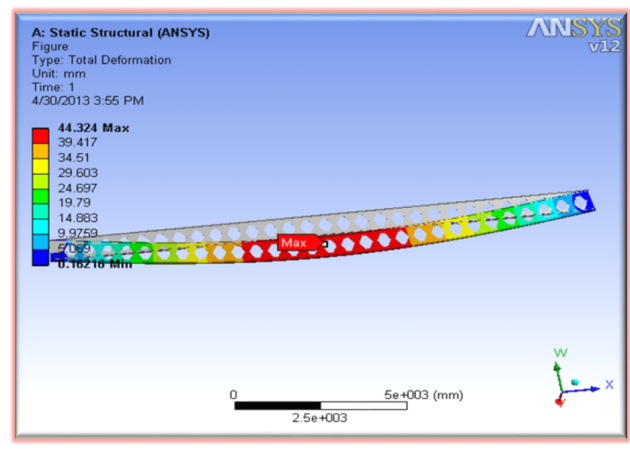

Figure 6: Hexagonal opening

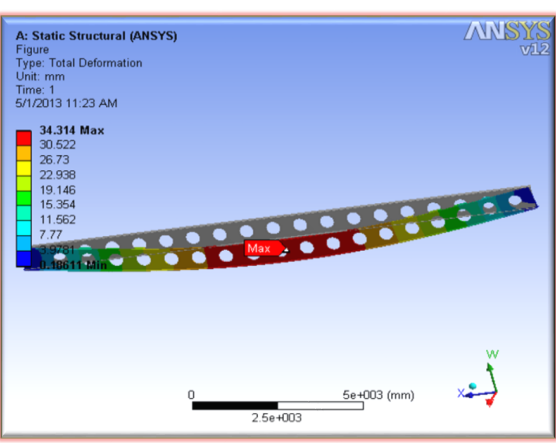

Figure 7: Circular opening

B. different shapes openings

In this comparison is carried out between deflection, Equivalent Stress, Maximum Shear Stress and Maximum Bending Stress for different shapes openings. Refer table 3 and graph1.

\begin{tabular}{|c|c|c|c|c|}
\hline Sr. No. & Description & Hexagonal & Circular & Square \\
\hline 1 & Deflection & $36.62 \mathrm{~mm}$ & $34.34 \mathrm{~mm}$ & $34.68 \mathrm{~mm}$ \\
\hline 2 & Equivalent Stress & $188.39 \mathrm{~N} / \mathrm{mm}^{2}$ & $119.96 \mathrm{~N} / \mathrm{mm}^{2}$ & $98.64 \mathrm{~N} / \mathrm{mm}^{2}$ \\
\hline 3 & $\begin{array}{c}\text { Maximum Shear } \\
\text { Stress }\end{array}$ & $96.88 \mathrm{~N} / \mathrm{mm}^{2}$ & $62.39 \mathrm{~N} / \mathrm{mm}^{2}$ & $51.28 \mathrm{~N} / \mathrm{mm}^{2}$ \\
\hline 4 & $\begin{array}{c}\text { Maximum } \\
\text { Bending Stress }\end{array}$ & 193.8 & 101.58 & 108.41 \\
& $\mathrm{~N} / \mathrm{mm}^{2}$ & $\mathrm{~N} / \mathrm{mm}^{2}$ & $\mathrm{~N} / \mathrm{mm}^{2}$ \\
\hline
\end{tabular}

Table 3: comparison between different shape of openings (square, circular and hexagonal)

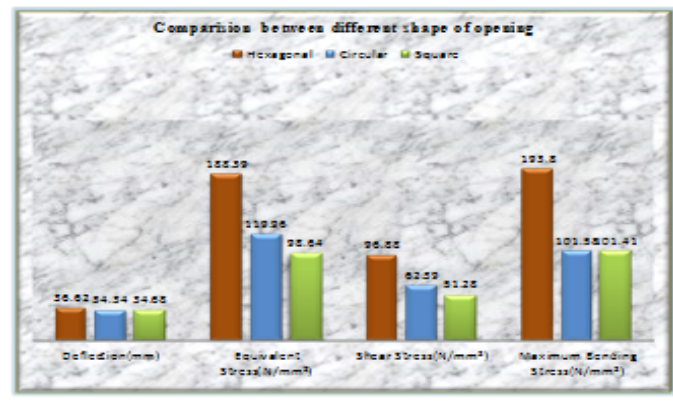

Graph 1: Comparison between different shapes of opening (square, circular \& hexagonal)

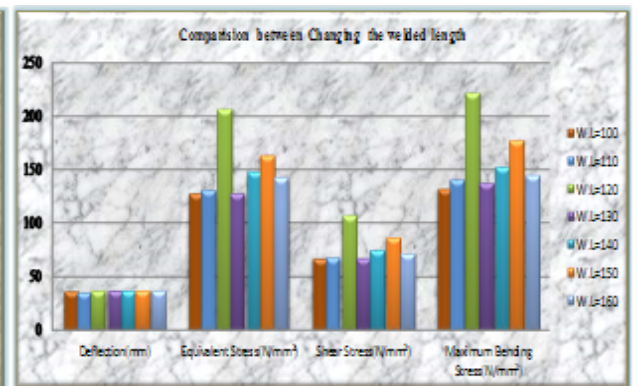

Graph 2: Comparison between different Welded lengths 
C. Different Welded length

In this comparison is carried out between deflection, Equivalent Stress, Maximum Shear Stress and Maximum Bending Stress for different Welded length. Refer table 4 and graph2.

\begin{tabular}{|c|c|c|c|c|c|c|c|}
\hline Description & $\mathrm{W} . \mathrm{L}=100$ & $\mathrm{~W} \cdot \mathrm{L}=110$ & $\mathrm{~W} . \mathrm{L}=120$ & $\mathrm{~W} . \mathrm{L}=130$ & $\mathrm{~W} \cdot \mathrm{L}=140$ & $\mathrm{~W} . \mathrm{L}=150$ & W.L $=160$ \\
\hline $\begin{array}{l}\text { Deflection, } \\
\mathrm{mm}\end{array}$ & 36.62 & 36.45 & 36.54 & 36.57 & 36.42 & 36.45 & 36.38 \\
\hline $\begin{array}{r}\text { Equivalent } \\
\text { Stress, N/mm }{ }^{2} \\
\end{array}$ & 127.45 & 130.91 & 206.85 & 127.44 & 147.58 & 163.31 & 142.19 \\
\hline $\begin{array}{c}\text { Maximum } \\
\text { Shear Stress, } \\
\mathrm{N} / \mathrm{mm}^{2} \\
\end{array}$ & 67.38 & 68.93 & 106.56 & 66.99 & 74.08 & 85.80 & 71.45 \\
\hline $\begin{array}{r}\text { Maximum } \\
\text { Bending Stress, } \\
\mathrm{N} / \mathrm{mm}^{2} \\
\end{array}$ & 132.77 & 141.07 & 221.36 & 137.3 & 151.85 & 177.57 & 144.39 \\
\hline
\end{tabular}

Table 4: comparison between different Welded lengths

D. In this comparison is carried out between deflection, Equivalent Stress, Maximum Shear Stress and Maximum Bending Stress for different Ratio of depth of opening to total depth. Refer table 5 and graph3.

\begin{tabular}{|r|c|c|c|c|c|c|}
\hline Sr. No & Description & $\mathbf{d} / \mathbf{D}=\mathbf{0 . 3}$ & $\mathbf{d} / \mathbf{D}=\mathbf{0 . 4}$ & $\mathbf{d} / \mathbf{D}=\mathbf{0 . 5}$ & $\mathbf{d} / \mathbf{D}=\mathbf{0 . 6}$ & $\mathbf{d} / \mathbf{D}=\mathbf{0 . 6 7}$ \\
\hline 1 & Deflection, $\mathrm{mm}$ & 33.57 & 35.82 & 34.79 & 35.82 & 36.62 \\
\hline 2 & Equivalent Stress, N/mm $\mathbf{m m}^{2}$ & 107.42 & 130.25 & 119.22 & 130.25 & 188.39 \\
\hline 3 & Maximum Shear Stress, N/mm & 55.48 & 66.17 & 61.96 & 66.17 & 96.88 \\
\hline 4 & $\begin{array}{c}\text { Maximum Bending Stress, } \\
\text { N/mm }\end{array}$ & 92.28 & 140.69 & 96.37 & 140.69 & 193.80 \\
\hline
\end{tabular}

Table 5: comparison for different Ratio of depth of opening to total depth

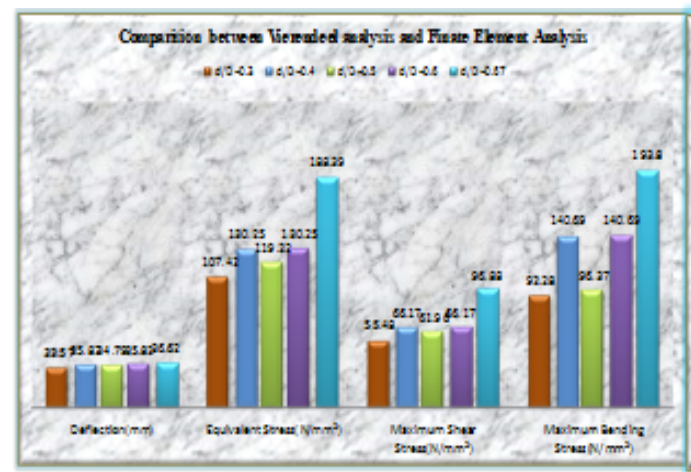

Graph 3: Comparison for different Ratio of depth of opening to total depth

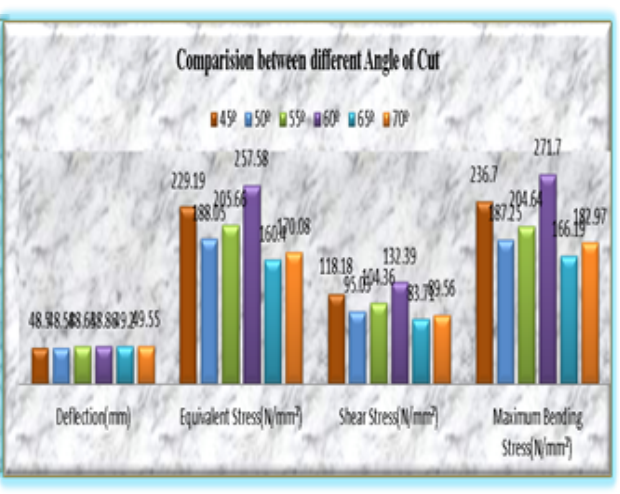

Graph 4: Comparison between different Angle of cuts

E. By Changing Angle of Cut

In this comparison is carried out between deflection, Equivalent Stress, Maximum Shear Stress and Maximum Bending Stress by Changing Angle of Cut. Refer table 6 and graph4.

\begin{tabular}{|c|c|c|c|c|c|c|c|}
\hline $\begin{array}{l}\text { Sr. } \\
\text { No }\end{array}$ & Description & $45^{\circ}$ & $50^{\circ}$ & $55^{\circ}$ & $60^{\circ}$ & $65^{\circ}$ & $70^{\circ}$ \\
\hline 1 & Deflection, $\mathrm{mm}$ & 48.50 & 48.58 & 48.63 & 48.86 & 49.20 & 49.55 \\
\hline 2 & Equivalent Stress, $\mathrm{N} / \mathrm{mm}^{2}$ & 229.19 & 188.05 & 205.66 & 257.58 & 160.40 & 170.08 \\
\hline 3 & Maximum Shear Stress, $\mathrm{N} / \mathrm{mm}^{2}$ & 118.18 & 95.03 & 104.36 & 132.39 & 83.71 & 89.56 \\
\hline 4 & Maximum Bending Stress, $\mathrm{N} / \mathrm{mm}^{2}$ & 236.7 & 187.25 & 204.64 & 271.70 & 166.19 & 182.97 \\
\hline
\end{tabular}

Table 6: comparison between different Angle of Cut 


\section{Result and Discussion}

In this paper, analysis of castellated beam is done by changing various parameters like welded length, ratio of depth of opening to the depth of beam, angle of cut etc. By changing welded length it is seen that maximum stresses occur at a length of 0.25 times the depth of hole and stresses are less at a length of 0.33 times the depth of hole.

By changing ratio of depth of opening to the depth of beam, it is seen that as ratio increases stresses are also increases. In most of castellated beam 45 or 60 degree angle of cut is provided. By changing different angle of cut it is seen that maximum stresses occur at 60 degree angle of cut and minimum stresses occur at 65 degree angle of cut.

It is seen that value of deflection is not depend on different parameters of hole. Different parameters of hole are affecting to stresses only.

\section{Conclusion}

By comparing castellated beam with solid beam it is concluded that solid beam required higher section than castellated beam for same loading and geometric condition. It is also found that higher section required in solid beam is due to the deflection only, because solid beam is safe in all checks like shear, bending, web buckling and web crippling but it is not safe in deflection. To minimize the deflection in solid beam higher section is required.

By changing shape of opening in castellated beam (i.e. Hexagonal, Square, Circular), it is concluded that there is no effect of shape of opening on deflection but shape of opening affect on stress concentration. Maximum stress concentration occur in Hexagonal shape of opening.

By changing welded length of castellated beam, it is concluded that there is no effect of welded length on deflection. Welded length depends upon depth of hole of castellated beam. Generally it is 0.25 times the depth of hole or 0.33 times the depth of hole is provided. It is also concluded that maximum stresses occur at a length of 0.25 times the depth of hole and stresses are less at a length of 0.33 times the depth of hole.

By changing ratio of depth of opening to total depth, it is concluded that as ratio increases stresses are also increases. Maximum stresses occur at ratio 0.67 and minimum at 0.3 .

By changing angle of cut in castellated beam, it is concluded that there is no effect of angle of cut in castellated beam but it affects on stresses. Generally 45 degree is minimum angle of cut and 70 degree is maximum angle of cut can be provided. In most of castellated beam 45 or 60 degree angle of cut is provided. By changing different angle of cut it is concluded that maximum stresses occur at 60 degree angle of cut and minimum stresses occur at 65 degree angle of cut.

\section{References}

H.showkati:-lateral-Torsional Buckling of castellated beams :-( 2008), Iranian journal of science \& technology, transaction $\mathrm{B}$, engineering.

Walid Zaaroue and Richard Redwood: - Web Buckling In Thin Webbed Castellated Beams :-( 1996), Journal of Structural Engineering

Miss Komal S. Bedi*, Mr. P.D.Pachpor**:- Moment and Shear Analysis of Beam with Different Web Openings (2011):- International Journal of Engineering Research and Applications

Richard Redwoodland Sevak Demirdjian: -Castellated Beam Web Buckling In Shear (1998):- Journal of Structural Engineering 
Wakchaure M.R. *, Sagade A.V.*, Auti V: - A Parametric study of castellated beam with varying depth of web opening (2012) :- (International Journal of Scientific and Research Publications)

ZHOU Chao-yang, LIU Chun-jie: - Calculation of flexural deflection for castellated beams (2007):- Journal of Railway science and engineering.

O. Kohnehpooshi, H. Showkati: - Numerical Modeling and Structural Behavior of Elastic Castellated Section (2009):European Journal of Scientific Research.

M.R.Wakchaure, A.V. Sagade: - Finite Element Analysis of Castellated Steel Beam (2012):- International Journal of Engineering and Innovative Technology (IJEIT).

Sherbourne AN. The plastic behavior of castellated beams. Proc. 2nd Commonwealth Welding Conference, Vol.C2. London: Inst. Of Welding; 1966. p. 1-5

M. M. Deshmukh , Prof. V. V. Agrawal A design comparison of Castellated beam between IS:-800-1984 and IS:800-2007, National conference on “ADVANCED TECHNOLOGY IN CIVIL ENGINEERING”, 8-9 March 2013.

Limit state design of steel structure by S.K.Duggal

Design of steel structure by N. Subramanian

Handbook for design of castellated beam by P.K.Das and S.L. Shrimani

IS 800-2007 "Indian standard code of practice for general construction in steel" 